\title{
Intellectual Capital, Good Corporate Governance, Pengungkapan Corporate Social Responbility dan Kinerja Keuangan Perusahaan
}

\author{
Olive Gracely Naomi Dumanauw ${ }^{1}$ \\ Fakultas Ekonomi dan Bisnis \\ Universitas Udayana, Indonesia
}

\author{
I Gusti Ngurah Agung Suaryana² \\ Fakultas Ekonomi dan Bisnis \\ Universitas Udayana, Indonesia
}

\begin{abstract}
Surel : gracely.olive@gmail.com
ABSTRAK

Penelitian ini dilakukan untuk menguji pengaruhintellectual capital, good corporate governance dan pengungkapan corporate social responsibility terhadap kinerja keuangan perusahaan yang terdaftar di Bursa Efek Indonesia periode 2014-2016. Penelitian ini adalah penelitian asosiatif. Populasi dari penelitian ini adalah 90 perusahaan dan diamati selama tahun 2014 hingga 2016. Teknik sampling yang digunakan dalam penelitian ini adalahpurposive sampling. Berdasarkan teknik ini, 30 perusahaan diperoleh sebagai sampel. Metode pengumpulan data yang digunakan dalam penelitian ini adalah metode observasi non partisipan. Peneliti menggunakan regresi linear berganda sebagai teknik analisis. Berdasarkan hasil analisis maka dapat disimpulkan bahwaIntellectual Capital tidak berpengaruh terhadap kinerja keuangan, good corporate governance dan pengungkapan corporate social responsibility berpengaruh terhadap kinerja keuangan.
\end{abstract}

Kata Kunci: Intellectual Capital; Good Corporate Governance; Corporate Social Responsibility; Kinerja Keuangan.

\section{Intellectual Capital, Good Corporate Governance, Disclosure of Corporate Social Responsibility and Company Financial Performance}

\begin{abstract}
This study was conducted to examine the effect of intellectual capital, good corporate governance and disclosure of corporate social responsibility on the financial performance of companies listed on the Indonesia Stock Exchange for the 2014-2016 period. This research is associative research. The population of this study was 90 companies and was observed during 2014 to 2016. The sampling technique used in this study was purposive sampling. Based on this technique, 30 companies were obtained as samples. The data collection method used in this study is a non-participant observation method. The researcher used multiple linear regression as an analysis technique. Based on the results of the analysis, it can be concluded that Intellectual Capital has no effect on financial performance, good corporate governance and disclosure of corporate social responsibility influences financial performance.
\end{abstract}

Keywords: Intellectual Capital; Good Corporate Governance; Corporate Social Responsibility; Financial Performance

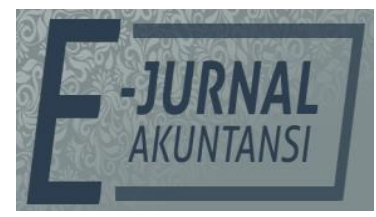

e-ISSN 2302-8556

Vol. 31 No. 3

Denpasar, Maret 2021

Hal. 635-651

DOI:

10.24843/EJA.2021.v31.i03.p09

PENGUTIPAN:

Dumanauw, O.G.N., \&

Wirasedana, P.W. (2021).

Intellectual Capital, Good

Corporate Governance,

Pengungkapan Corporate

Social Responbility dan

Kinerja Keuangan

Perusahaan. E-Jurnal

Akuntansi, 31(3), 635-651

RIWAYAT ARTIKEL:

Artikel Masuk:

27 Maret 2019

Artikel Diterima:

25 Maret 2021

Artikel dapat diakses : https://ojs.unud.ac.id/index.php/Akuntansi/index 


\section{PENDAHULUAN}

Salah satu cara investor melakukan pengambilan keputusan untuk berinvestasi di suatu perusahaan yaitu dengan cara menilai kinerja keuangan dalam perusahaan (Silvia \& Andayani, 2014). Kinerja keuangan perusahaan adalah suatu gambaran tentang kondisi keuangan suatu perusahaan yang dianalisis dengan alat-alat analisis keuangan, sehingga dapat diketahui mengenai baik buruknya keadaan keuangan suatu perusahaan yang mencerminkan prestasi kerja dalam periode tertentu (Dwiermayanti, 2009) dalam (Wati (2012). Kinerja keuangan yang baik akan meningkatkan nilai perusahaan pada investor, meningkatnya nilai perusahaan merupakan harapan perusahaan karena akan menunjukan kemakmuran pemegang saham (Stanley, 2017). Hal itu juga merupakan tujuan yang seharusnya dicapai oleh perusahan untuk mempengaruhi persepsi stakeholders dalam berinvestasi sehingga membantu menunjang kegiatan operasional perusahaan.

Penilaian kinerja keuangan dilakukan agar pihak masyarakat dan pelanggan yakin serta percaya bahwa perusahaan tersebut memiliki kredibilitas yang baik. Sedangkan bagi pihak internal, kinerja keuangan yang tercermin di laporan keuangan dapat digunakan untuk pengambilan keputusan terkait dengan mengatasi kelemahan-kelemahan yang ada dan penentuan strategi serta kebijakan secara tepat (Kartikasari, 2016). Dengan demikian, kinerja keuangan perusahaan disebut juga suatu penentuan yang mengukur mengenai baik buruknya perusahaan dalam prestasi kerja dapat dilihat dari kondisi keuangannya pada periode tertentu. Kondisi keuangan dianalisis dengan alatalat analisis keuangan. Beberapa alat-alat analisis keuangan yang dapat digunakan untuk menilai kinerja keuangan suatu perusahaan, yaitu Intellectual Capital (IC), Good Corporate Governance (GCG), dan Corporate Social Responsibility (CSR).

Selama dekade terakhir, pertimbangan Intellectual Capital (IC) semakin penting. IC semakin dilihat sebagai kontributor penting untuk proses penciptaan nilai dan kinerja dalam perusahaan (Sullivan 2000) dalam (Razafindrambinina, 2011). IC yang baik akan menjadi salah satu faktor yang akan menambah nilai bagi perusahaan yaitu apabila perusahaan dapat mengembangkan kemampuan dalam memotivasi karyawannya agar dapat berinovasi dan meningkatkan produktivitasnya, serta memiliki sistem dan struktur yang dapat membantu perusahaan dalam mempertahankan bahkan meningkatkan profitabilitas dan eksistensinya. Perusahaan yang mampu mengelola dan memanfaatkan kekayaan intelektualnya dengan baik diyakini dapat meningkatkan kinerja keuangan perusahaan. Akan tetapi, implementasi IC merupakan sesuatu yang masih baru di Indonesia bahkan di lingkungan bisnis global. Hanya beberapa negara maju yang telah menerapkan konsep ini, antara lain Australia, Amerika dan Rusia.

Pada umumnya kalangan bisnis masih belum menemukan jawaban yang tepat mengenai nilai lebih apa yang dimiliki oleh perusahaan. Nilai lebih ini sendiri dapat berasal dari kemampuan berproduksi suatu perusahaan sampai pada loyalitas pelanggan terhadap perusahaan (Mualim, 2009). Nilai ini sesungguhnya dapat dihasilkan dengan cara mengimplementasikan IC dalambudaya pengembangan perusahaan maupun kemampuan perusahaan 
dalam memotivasi karyawannya sehingga kinerja keuangan perusahaan dapat meningkat (Supriatna et al., 2013).

Fenomena "The Death of Samurai" yang terjadi pada tahun 2012 adalah salah satu kegagalan Panasonic yang merupakan perusahaan raksasa di Jepang karena belum mengedepankan IC. Harmony culture error yang terjadi dalam manajemen Panasonic menjadi penyebab jatuhnya perusahaan elektronik tersebut, dimana pada era digital seperti saat ini, kecepatan adalah kunci. Speed in decision making, speed in product development, dan speed in product launch, dalam hal ini perusahaan Jepang tertinggal dikarenakan budaya mereka yang sangat mengagungkan harmoni dan consensus (Devi \& Budiono, 2017). Kasus yang sama juga terjadi pada Bisnis convenience store dari PT. Modern Sevel Indonesia yang telah eksis di Indonesia sejak tahun 2009. 7-Eleven merupakan pelopor convenience store pertama di Indonesia dan diikuti oleh beberapa kompetitor lainnya. Sebagai salah satu convenience store, 7-Eleven memberikan kenyamanan bagi pelanggannya, salah satunya dengan memberikan jaringan Internet gratis. Oleh karena itu, 7-Eleven selalu diramaikan oleh pengunjung dari pelajar, mahasisiwa, hingga orang-orang kantoran. Namun, pada Tanggal 30 Juni 2017, Seven Eleven resmi ditutup karena beberapa alasan, salah satunya adalah keterbatasan sumber daya yang dimiliki perseroan dalam menunjang kegiatan operasional toko (Utami, 2017).

Terjadinya fenomena Panasonic dan 7-Eleven menunjukan bahwa inovasi yang merupakan bagian dari IC sangat penting bagi suatu perusahaan. Pada masa pasar bebas seperti ini persaingan ekonomi global sangat kuat, untuk menghadapi kuatnya persaingan ekonomi global, diungkapkan bahwa pengakuan IC adalah sebuah kekuatan yang menggerakkan pertumbuhan ekonomi Huang \& Liu dalam (Sharabati et al. 2010).

Berbeda dengan dua fenomena sebelumnya, adanya Fenomena Unicorn merupakan salah satu fenomena ekstrim mengenai peningkatan pengelolaan intellectual capital di Indonesia. Fenomena Unicorn membuat Menteri Keuangan Sri Mulyani Indrawati mendukung adanya peningkatan kualitas sumber daya manusia (SDM) untuk mendorong penguatan perusahaan startup lokal yang sudah memiliki valuasi nilai hingga satu miliar dolar AS atau Unicorn. Dalam dunia startup- perusahaan rintisan di bidang teknologi Unicorn adalah gelar bagi perusahaan rintisan yang memiliki nilai valuasi lebih dari 1 miliar dolar. Istilah ini pertama kali diperkenalkan oleh Aileen Lee, investor pendiri Cowboy Ventures, dalam artikelnya "Welcome to The Unicorn Club" yang terbit di Techcrunch pada 2013. Indonesia saat ini memiliki empat unicorn yaitu Go-Jek, Traveloka, Tokopedia, dan Bukalapak.Investasi SDM menjadi sangat penting dan dapat dilakukan dengan memberikan dukungan untuk pembenahan pendidikan vokasi maupun kepada universitas agar kehidupan riset dan pengembangan dalam teknologi informasi dapat menghasilkan inovasi yang berguna. Upaya lain yang dilakukan untuk mendorong penguatan Unicorn adalah mencari skema yang tepat terkait dengan perpajakan agar sesuai kondisi terkini dan tidak menganggu kelangsungan usaha dari industri e-commerce (Anggit, 2019).

Selain perusahaan harus mampu mengelola dan memanfaatkan IC, pengelolaan manajemen yang sehat juga merupakan salah satu faktor yang 
dipertimbangkan oleh stakeholders guna menunjang kegiatan operasional perusahaan. Perusahaan juga harus berpedoman pada prinsip-prinsip Good Corporate Governance untuk meningkatkan kinerja keuangan perusahaan, melindungi stakeholders dan meningkatkan kepatuhan terhadap peraturan perundang-undangan yang berlaku secara umum perusahaan wajib melaksanakan kegiatan usahanya dengan berpedoman pada prinsip-prinsip Good Corporate Governance (GCG). GCG merupakan tata kelola yang mengarahkan dan mengatur perusahaan untuk menciptakan nilai tambah (value added) dalam menentukan arah kinerja perusahaan. Isu-isu mengenai GCG mulai ada khususnya di Indonesia pada tahun 1998 ketika Indonesia mengalami krisis yang berkepanjangan. Banyak pihak yang mengatakan proses perbaikan di Indonesia memakan waktu yang lama disebabkan karena lemahnya GCG yang diterapkan dalam perusahaan Indonesia. Sejak saat itu baik pemerintah maupun stakeholders mulai memberikan perhatian yang cukup dalam pada penerapan GCG (Silvia \& Andayani, 2014).

Pendiri sekaligus Direktur Utama Economic Review yang menyelenggarakan Indonesia Good Corporate Governance Award 2017 mengatakan masih banyak perusahaan yang terpuruk karena penerapan GCG tidak baik sehingga tidak dapat menarik investor untuk berinvestasi sehingga penting bagi sebuah perusahaan untuk memiliki pengetahuan tentang GCG dalam menjalankan roda bisnisnya. Adapun para pemenang Indonesia Good Corporate Governance Award 2017 berasal dari perusahaan BUMN, Swasta, BUMD, BPD, BPR, Perusahaan Asuransi, dan Perusahaan Multifinance. Melalui penghargaan ini, diharapkan perusahaan terpacu meningkatkan prestasi dan peran pentingnya dalam implementasi praktik Good Corporate Governance dalam perusahaan-perusahaan di Indonesia (Embu, 2017).

Dunia usaha akhir-akhir ini juga memberikan perhatian lebih pada informasi pertanggung jawaban sosial atau disebut juga Corporate Sosial Responsibility (CSR) yang diungkapkan dalam laporan tahunan perusahaan. CSR merupakan bentuk tanggung jawab perusahaan terhadap lingkungan atas dampak yang ditimbulkan oleh aktivitas operasional perusahaan. Di Indonesia wacana mengenai CSR mulai mengemuka pada tahun 2001, namun sebelum wacana ini mengemuka telah banyak perusahaan yang menjalankan CSR dan sangat sedikit yang mengungkapkannya dalam sebuah laporan. Hal ini terjadi mungkin karena belum mempunyai sarana pendukung seperti: standar laporan, tenaga terampil baik penyusun laporan maupun auditornya. Di samping itu sektor pasar modal Indonesia juga kurang mendukung dengan belum adanya penerapan indeks yang memasukkan kategori saham-saham perusahaan yang telah mempraktikkan CSR (Silvia \& Andayani, 2014). Padahal CSR merupakan keberpihakan perusahaan terhadap masyarakat sehingga masyarakat mampu memilih produk yang baik yang di nilai tidak hanya dari barangnya saja tetapi juga melalui tata kelola perusahaannya. Pada saat masyarakat yang menjadi pelanggan memiliki penilaian yang positif terhadap perusahaan, maka mereka akan loyal terhadap produk yang dihasilkan, hal ini akan mampu menaikkan citra perusahaan yang direfleksikan melalui kinerja perusahaan yang akan meningkat (Rodriguez-Fernandez, 2016). 
Dalam beberapa tahun terakhir, semakin banyak perusahaan yang mengadopsi berbagai tanggung jawab social perusahaan (CSR) inisiatif penggabungan sukarela isu-isu sosial dan lingkungan ke dalam model bisnis perusahaan dan operasi (Embu, 2017) dalam upaya untuk memenuhi kebutuhan dan harapan dari berbagai pemangku kepentingan, termasuk pemegang saham perusahaan (Ioannou \& Serafeim, 2015). Salah satu perusahaan yang menerapkan CSR yaitu Danone Aqua yang memiliki program CSR yang disebut WASH (Water Access, Sanitation, Hygiene Program) yang bertujuan untuk meningkatkan lingkungan bagi masyarakat pra-sejahtera. Melalui program WASH, Aqua berkontribusi secara aktif dan berkelanjutan untuk memberikan solusi atas berbagai permasalahan yang berkaitan dengan penyediaan air bersih di Indonesia. Aqua berhasil mendapatkan penghargaan dari Metro TV dalam kategori pelestarian lingkungan (environmental sustainability) atas program " $1 \mathrm{~L}$ Aqua Untuk 10L Air Bersih" yang merupakan bagian dari program WASH (water access, sanitation and hygiene). Penghargaan-penghargaan tersebut jelas meningkatkan citra Aqua sebagai perusahaan yang peduli terhadap lingkungan dan masyarakat sekitar. Sementara dari segi financial, melalui program " $1 \mathrm{~L}$ Aqua Untuk 10L Air Bersih" ini dianggap berhasil mendongkrak pendapatan bersih perusahaan sebesar 19,4\% selang waktu satu tahun (Moon, 2013).

CSR dapat memiliki keuntungan finansial dan strategis bagi perusahaan. Dengan terlibat dalam kegiatan sosial dan pelaporan tentang CSR, perusahaan mengembangkan kepercayaan dan niat baik dari para pemangku kepentingan, yang dapat memberi mereka keuntungan kompetitif (Jizi et al., 2014). Sebagai sebuah fenomena organisasi, CSR telah menjadi lebih umum dan terlihat di dalam perusahaan sebagai mekanisme untuk memberi energi dan memotivasi para pemangku kepentingan (stakeholders), serta mengelola persepsi dan harapan masyarakat tentang peran dan kegunaan bisnis di masyarakat dan masyarakat di luar fungsi inti dalam memproduksi dan menjual barang ke pasar konsumen yang ditentukan (Wang et al., 2016).

Pengungkapan CSR merupakan bentuk pengungkapan non financial yang penting dan khas mengandung banyak informasi, seperti pengeluaran yang berkaitan dengan perlindungan lingkungan dan perubahan iklim, sumbangan amal, dan kesejahteraan karyawan yang semuanya biasanya tidak dilaporkan dalam laporan keuangan tetapi memiliki implikasi signifikan untuk menilai nilai perusahaan (Dhaliwal et al., 2014). Adopsi dan implementasi kebijakan CSR serta ketersediaan skor CSR, sebenarnya telah menghasilkan minat yang berkembang oleh pasar keuangan, dan analis investasi khususnya (Ioannou \& Serafeim, 2015). Dengan demikian, mengingat peran penting yang dimainkan pasar keuangan dalam alokasi sumber daya modal yang langka dan dalam derivasi nilai pasar perusahaan, memahami apakah dan dengan cara apa pasar-pasar ini menilai nilai CSR perusahaan sangat penting (Ioannou \& Serafeim, 2015).

Beberapa penelitian yang meneliti tentang pengaruh Intellectual Capital, Good Corporate Governance dan Corporate Social Responsibility terhadap kinerja keuangan menunjukan hasil yang berbeda dan adanya hasil yang tidak konsisten. Beberapa hasil penelitian mengenai proksi intellectual capital menunjukan hasil yang berbeda yaitu; Hasil penelitian Andriana (2014), menunjukan bahwa tidak adanya pengaruh signifikan dari intellectual capital, 
capital employed, human capital, dan structural capital, terhadap kinerja keuangan perusahaan dan hasil penelitian Prasetio (2015), menunjukan bahwa human capital efficiency, Hasil penelitian Supriatna et al. (2013) intellectual capital berpengaruh secara negatif dan signifikan terhadap produktivitas (ATO), dan capital employed efficiency coefficient tidak berpengaruh terhadap kinerja keuangan. Hasil penelitian Maryanti \& Fithri (2017) menunjukan GCG yang dibentuk dengan kepemilikan institusi dan komite audit tidak berpengaruh terhadap kinerja keuangan perusahaan dan hasil penelitian Kartikasari (2016) menunjukan bahwa GCG dengan proksi proporsi komisaris independen tidak berpengaruh signifikan terhadap kinerja keuangan dan dewan komisaris berpengaruh negatif terhadap kinerja keuangan. Hasil penelitian Candrayanthi \& Saputra (2013) menunjukan bahwa variabel Corporate Social Responsibility berpengaruh negatif terhadap Kinerja Keuangan Perusahaan yang diukur dengan Net Profit Margin (NPM).

Penelitian mengenai kinerja keuangan telah banyak dilakukan tetapi hanya berfokus pada salah satu sektor dari sembilan sektor perusahaan yang ada di BEI. Oleh karena itu, peneliti tertarik untuk melakukan penelitian kembali tentang pengaruh Intellectual Capital, Good Corporate Governance dan Pengungkapan Corporate Social Responsibility terhadap Kinerja Keuangan pada semua sektor perusahaan yang ada di BEI. Perbedaan penelitian ini dengan sebelumnya yaitu penelitian menggunakan pemeringkatan CGPI (Corporate Governance Perception Index) dengan kategori Most Trusted Company yang dikeluarkan oleh IICG (The Indonesian Institute for Corporate Governance).

$\mathrm{H}_{1}$ : Intellectual capital tidak berpengaruh terhadap kinerja keuangan.

Freeman et al. (2007) mendiskusikan tentang pengaruh stakeholder dalam keputusan yang diambil perusahaan. Peran utama dari manajemen perusahaan adalah untuk menilai pentingnya memenuhi permintaan stakeholder dalam rangka untuk mencapai tujuan strategis perusahaan. Ketika derajat kekuatan stakeholder meningkat, maka pentingnya laporan informasi untuk memenuhi permintaan stakeholder juga meningkat. Selanjutnya, harapan dan kekuatan berbagai macam stakeholder dapat berubah sewaktu-waktu, sehingga perusahaan harus menyesuaikan secara terus menerus strategi operasional dan pelaporannya (Simarmata, 2015).

GoodCorporate Governance merupakan sistem dan struktur yang baik untuk mengelola perusahaan dengan tujuan meningkatkan nilai pemegang saham serta mengakomodasi berbagai pihak yang berkepentingan dengan perusahaan (stakeholders) dan sebagai struktur, sistem, dan proses yang digunakan oleh organ-organ perusahaan sebagai upaya untuk memberikan nilai tambah perusahaan secara berkesinambungan dalam jangka panjang, dengan tetap memperhatikan kepentingan stakeholder lainnya, berlandasarkan peraturan perundang-undangan dan norma yang berlaku, sehingga dapat meningkatkan minat stakehorlders untuk berinvestasi dan meningkatkan kinerja keuangan perusahaan.

Kartikasari (2016) menyatakan bahwa Good Corporate Governance dengan proksi (1) Dewan Direksi berpengaruh positif terhadap Kinerja Keuangan dengan proksi Dewan Komisaris berpengaruh negatif terhadap Kinerja Keuangan (3) Proporsi Komisaris Independen tidak berpengaruh signifikan 
terhadap Kinerja Keuangan dengan (4) Komite Audit berpengaruh positif terhadap Kinerja Keuangan, (5) Kepemilikan Institusional berpengaruh positif terhadap Kinerja Keuangan. Hasil penelitian serupa juga diungkap oleh (Mary, 2017) yaitu Good Corporate Governance (GCG) berpengaruh signifikan terhadap kinerja keuangan perusahaan dengan variabel kepemilikan manajerial, kepemilikan institusional, dan independensi komite audit. Semakin tinggi kepemilikan manajerial, kepemilikan institusional, dan independensi komite audit, maka akan meningkatan kinerja sebuah perusahan. Berdasarkan dengan teori dan hasil penelitian empiris tersebut maka dapat dibuat hipotesis penelitian sebagai berikut.

$\mathrm{H}_{2}$ : Penerapan Good Corporate Governanceberpengaruh positifterhadap Kinerja Keuangan Perusahaan.

Legitimasi dapat dianggap sebagai menyamakan persepsi atau asumsi bahwa tindakan yang dilakukan oleh suatu organisasi selaras dengan tindakan yang diinginkan, pantas ataupun sesuai dengan sistem nilai, norma, kepercayaan yang berkembang di masyarakat. Menurut teori Stakeholders, perusahaan bukanlah entitas yang hanya beroperasi untuk kepentingan sendiri, namun harus memberikan manfaat kepada seluruh stakeholder-nya yakni pemegang saham, kreditor, konsumen, supplier, pemerintah, masyarakat, analis, dan pihak lain (Ghazali, 2007). Perusahaan akan mengungkapkan suatu informasi jika informasi tersebut dapat berdampak pada peningkatan kinerja perusahaan apabila dilihat dari perspektif ekonomi. Dengan melakukan kegiatan CSR perusahaan dapat memperoleh legitimasi dari masayarakat dan mempertahankan hubungan dalam lingkungan sosial dimana mereka beroperasi agar dapat mempertahankan loyalitas masyarakat dan meningkatkan kinerja keuangan perusahaan. Menurut Silvia \& Andayani (2014) istilah CSR pertama kali ada dalam tulisan Sosial Reponsibility of the Businessman tahun 1953. Konsep yang digagas Howard Rothmann Browen ini menjawab keresahan dunia bisnis. Howard Rothmann Browen mengungkapkan bahwa keberadaan CSR bukan karena diwajibkan oleh pemerintah atau penguasa, melainkan merupakan komitmen yang lahir dalam konteks etika bisnis (beyond legal aspects) agar sejahtera bersama masyarakat berdasarkan prinsip kepentasan sesuai nilai dan kebutuhan masyarakat. Tanggung jawab sosial dan lingkungan, yaitu merupakan komitmen perseroan untuk berperan serta dalam pembangunan ekonomi berkelanjutan guna meningkatkan kualitas kehidupan dan lingkungan yang bermanfaat baik bagi perseroan sendiri, komunitas setempat, maupun masyarakat pada umumnya.

Ariantini et al. (2017) menyatakan bahwa Corporate Social Responsibility berpengaruh terhadap kinerja perusahaan. Hasil penelitian serupa juga diungkap oleh Sari \& Suaryana (2013) yaitu pengungkapan CSR berpengaruh positif dan signifikan terhadap kinerja keuangan. Ini berarti semakin tinggi pengungkapan CSR, semakin tinggi kinerja keuangan perusahaan. Berdasarkan dengan teori dan hasil penelitian empiris tersebut maka dapat dibuat hipotesis penelitian sebagai berikut.

$\mathrm{H}_{3}$ : Pengungkapan Corporate Social Responsibility berpengaruh positif terhadap Kinerja Keuangan Perusahaan 


\section{METODE PENELITIAN}

Lokasi dari penelitian ini dilakukan pada Bursa Efek Indonesia dengan meneliti perusahaan-perusahaan yang terdaftar di Bursa Efek Indonesia (BEI) selama 3 tahun periode 2014 sampai dengan 2016 yang mengikuti pemeringkatan CGPI (Corporate Governance Perception Index) oleh IICG (The Indonesian Institute of Corporate Governance). Lokasi penelitian ini dapat diakses melalui situs resmi Bursa Efek Indonesia (BEI) yaitu www.idx.co.id dan majalah SWA yang dipublikasikan oleh IICG. Di dalam situs tersebut tersedia data-data yang diperlukan dan yang mendukung penelitian ini.

Tahap pertama yakni menghitung value added. Value addedmerupakan indikator yang sesuai untuk kesuksesan bisnis, Pulic (1998) menyatakan bahwa value addeddapat dihitung dari selisih antara output dan input.

$\mathrm{VA}=\mathrm{OUT}-\mathrm{IN}$

Dimana : VA= selisih antara OUT dan IN; OUT= total penjualan dan pendapatan : IN= beban (beban bunga dan beban operasional) dan biaya lainlain (selain beban karyawan).

Tahap kedua yaitu menghitung HCE. HCE digunakan untuk melihat berapa banyak nilai tambah (value added) yang dihasilkan oleh perusahaan setiap satu rupiah yang diinvestasikan dalam tenaga kerja.

$\mathrm{HCE}=\frac{V A}{H C}$.

Dimana: HCE= humann capital efficiency coefficient perusahaan; $\mathrm{HC}=$ total beban gaji dan tunjangan; $\mathrm{VA}=$ value added.

Tahapan selanjutnya yakni menghitung SCE. Rasio ini mengukur jumlah SC yang dibutuhkan untuk menghasilkan 1 rupiah dari VA dan merupakan indikasi bagaimana keberhasilan SC dalam penciptaan nilai (Ulum, 2008). Menurut Pulic (1998) semakin besar konstribusi HC dalam value creation, maka akan semakin kecil kontribusi SC dalam hal tersebut.

$\mathrm{SCE}=\frac{S C}{V A}$

Dimana: $\mathrm{SCE}=$ structuural capital efficiency coefficient perusahaan; $\mathrm{SC}=\mathrm{VA}-\mathrm{HC}$; $\mathrm{VA}=$ value added

Tahap ketiga yaitu menghitung RCE. RCE digunakan untuk melihat berapa banyak nilai tambah (value added) yang dihasilkan oleh perusahaan setiap satu rupiah yang diinvestasikan dalam biaya pemasaran.

$\mathrm{RCE}=\frac{V A}{R C}$.

Dimana: $\mathrm{RCE}=$ relational capital efficiency coefficientperusahaan; $\mathrm{RC}=$ total beban pemasaran/marketing cost Nazari dan Herremans (2007) (dalam Ulum, 2015) ; $\mathrm{VA}=$ value added.

Tahapan kelima yaitu menghitung CEE. Intelektual kapital (intellectual capital) tidak dapat menghasilkan nilai tambah apabila tidak didukung dengan physical capital atau capital employed.

$\mathrm{CEE}=\frac{V A}{C E}$.

Dimana: $\mathrm{CEE}=$ capital employed efficiency coefficient perusahaan; $\mathrm{CE}=$ jumlah ekuitas dan laba bersih; $\mathrm{VA}=$ value added

Tahap terakhir yaitu menghitungModified Value Added Intellectual Coefficient (VAICTM). VAICTM merupakan penjumlahan dari 3 komponen 
sebelumnya, dan mengindikasikan kemampuan intellectual capital organisasi yang dapat juga dianggap sebagai BPI (Business Perfomance Indikator). Maka rumusnya:

VAICTM $=$ VACA + VAHU + STVA

Dimana:

VAICTM= modified value added intellectual coefficient;

VACA : Rasio dari VA terhadap CA

VAHU :Rasio dari VA terhadap HU

STVA : Rasio dari VA terhadap SC

Populasi dalam penelitian ini adalah seluruh perusahaan yang masuk dalam pemeringkatan CGPI tahun 2014-2016. Sampel dalam penelitian ini adalah perusahaan yang tercatat di Bursa Efek Indonesia yang masuk dalam pemeringkatan CGPI kategori Most Trusted Company tahun 2014-2016..

Penelitian ini menggunakan metode kuantitatif dengan alat analisis regresi linier berganda yang seberapa besar variabel independen mempengaruhi variabel dependen dihitung dengan menggunakan persamaan garis regresi linier berganda berikut: Persamaan regresi linier berganda (Puniayasa \& Triaryati 2016).

$Y=\alpha+\beta 1 X 1+\beta 2 X 2+\beta 3 X 3+\varepsilon$

Keterangan:

$$
\begin{array}{ll}
\mathrm{Y} & =\text { Return on Equity } \\
\mathrm{a} & =\text { Konstanta } \\
\beta 1-\beta 4 & =\text { Koefisien Regresi } \\
\mathrm{X} 1 & =\text { Intellectual Capital } \\
\mathrm{X} 2 & =\text { Good Corporate Governance } \\
\mathrm{X} 3 & =\text { Corporate Social Responsibility } \\
\varepsilon & =\text { Error }
\end{array}
$$

\section{HASIL DAN PEMBAHASAN}

Statistik deskriptif disajikan untuk memberikan informasi mengenai karakteristik variabel-variabel penelitian, antar yang lain rata-rata dan standar deviasi. Adapun hasil statistik deskriptif dapat dilihat pada tabel berikut.

Tabel 1. Statistik Deskriptif

\begin{tabular}{llllll}
\hline & $\mathrm{N}$ & Minimum & Maximum & Mean & Std. Deviation \\
\hline IC & 30 & -.30 & 5.10 & 2.1638 & 1.40539 \\
GCG & 30 & 85.25 & 93.32 & 87.4793 & 2.19638 \\
CSR & 30 & .34 & .65 & .5237 & .08692 \\
Kinerja Keuangan & 30 & -1440.85 & 20334.97 & 1794.5679 & 5588.30800 \\
Valid N (listwise) & 30 & & & & \\
\hline
\end{tabular}

Sumber: Data Penelitian, 2018

Berdasarkan Tabel 1, Intellectual Capital memiliki nilai rata-rata sebesar 2.1638, nilai standar deviasi sebesar 1.40539. Nilai minimum sebesar -30 dan nilai maksimumnya sebesar 5.10. Good Corporate Governance memiliki nilai rata-rata sebesar 87.4793, standar deviasi sebeesar 2.19638, nilai minimum sebesar 85.25 dan nilai maksimumnya sebesar .65. Corporate Social Responsibility memiliki nilai rata-rata sebesar .5237, nilai standar deviasi sebesar .08692, nilai minimum sebesar .34, dan nilai maksimum sebesar .65. Kinerja Keuangan memiliki nilai 
rata-rata sebesar 1794.5679, nilai standar deviasi sebesar 5588.30800, nilai minimum sebesar -1440.85, dan nilai maksimum sebesar 20334.97.

Tabel 2. Hasil Uji Analisis Regresi Linier Berganda

\begin{tabular}{|c|c|c|c|c|c|}
\hline \multirow[t]{2}{*}{ Model } & \multicolumn{2}{|c|}{ Unstandardized Coefficients } & \multirow{2}{*}{$\begin{array}{c}\text { Standardized } \\
\text { Coefficients } \\
\text { Beta }\end{array}$} & \multirow[t]{2}{*}{$\mathrm{T}$} & \multirow[t]{2}{*}{ Sig. } \\
\hline & B & Std. Error & & & \\
\hline$($ Constant $)$ & $-191660,805$ & 19181,246 & & $-9,992$ & 0,000 \\
\hline IC & 620,778 & 340,999 & 0,156 & 1,820 & 0,080 \\
\hline GCG & 2100,880 & 222,980 & 0,826 & 9,422 & 0,000 \\
\hline CSR & 15904,898 & 5562,335 & 0,247 & 2,859 & 0,008 \\
\hline $\mathrm{R}$ & 0,904 & & & & \\
\hline $\mathrm{R}^{2}$ & 0,818 & & & & \\
\hline Adjusted $\mathrm{R}^{2}$ & 0,796 & & & & \\
\hline F hitung & 38,823 & & & & \\
\hline Sig. F & 0,000 & & & & \\
\hline
\end{tabular}

Sumber: Data Penelitian, 2018

Berdasarkan perhitungan analisis regresi linear berganda, maka didapatkan hasil persamaan regresi sebagai berikut.

$$
Y=-191660,805+620,778 X_{1}+2100,880 X_{2}+15904,898 X_{3}
$$

Berdasarkan hasil uji, nilai signifikansi $\mathrm{F}$ adalah sebesar 0,000 yang lebih kecil dari 0,05 ( $\mathrm{F}<\mathrm{a})$ yang berarti variabel bebas yaitu Intellectual Capital $\left(\mathrm{X}_{1}\right)$, Good Corporate Governance $\left(\mathrm{X}_{2}\right)$, dan Pengungkapan Corporate Social Responsibility $\left(\mathrm{X}_{3}\right)$ berpengaruh signifikan secara serempak atau bersama-sama terhadap variabel terikat yaitu kinerja keuangan $(Y)$, sehingga penelitian ini dapat dikatakan memenuhi uji kelayakan model atau model penelitian dinyatakan layak digunakan sebagai model regresi.

Uji Normalitas bertujuan untuk menguji apakah data yang digunakan normal atau tidak dapat dilakukan dengan menggunakan uji Kolmogorov-Smirnov dengan melihat nilai Asymp. Sig. (2-tailed). Jika nilai Asymp. Sig. (2-tailed) lebih besar taraf signifikansi yang ditetapkan yaitu 5 persen $(0,05)$, maka data telah berdistribusi normal. Berdasarkan hasil analisis, diperoleh hasil sebesar 0,936 > 0,05 yang artinya data berdistribusi normal.

\section{Tabel 3. Hasil Uji Normalitas}

\begin{tabular}{lr}
\hline $\mathrm{N}$ & Unstandardized Residual \\
Kolmogorov-Smirnov Z & 30 \\
Asymp. Sig. (2-tailed) & 0,537 \\
\hline
\end{tabular}

Sumber: Data Penelitian, 2018

Untuk mendeteksi ada atau tidaknya multikolinearitas dalam model regresi yaitu mempunyai angka Tolerance $>0,10$ atau mempunyai nilai VIF $<10$. Berdasarkan hasil analisis, dapat dilihat bahwa koefisien Tolerance semua variabel lebih besar dari 0,10 dan nilai VIF yang lebih kecil dari 10. Hasil ini mengindikasikan bahwa tidak terdapat gejala multikolinear dari model regresi yang dibuat sehingga pada model regresi ditemukan korelasi antar variabel bebas. 
Tabel 4. Hasil Uji Multikolinearitas

\begin{tabular}{|c|c|c|}
\hline \multirow[t]{2}{*}{ Model } & \multicolumn{2}{|c|}{ Colinearity Statistic } \\
\hline & Tolerance & VIF \\
\hline Intellectual Capital(X1) & 0,954 & 1,048 \\
\hline Good Corporate Governance(X2) & 0,914 & 1,094 \\
\hline Pengungkapan Corporate Social Responsibility (X3) & 0,938 & 1,066 \\
\hline
\end{tabular}

Sumber: Data Penelitian, 2018

Untuk dapat mengetahui ada tidaknya autokorelasi yaitu dengan melakukan Uji Durbin-Watson (DW). Hasil menunjukkan bahwa nilai DW sebesar 1,810 dengan nilai $d_{U}$ untuk 30 sampel dengan 3 variabel bebas adalah 1,6498 dan nilai 4- $\mathrm{d}_{\mathrm{U}}$ adalah 2,3502. Oleh karena nilai $\mathrm{d}_{\mathrm{U}}<\mathrm{DW}<4-\mathrm{d}_{\mathrm{U}}(1,6498<$ $1,810<2,3502)$, maka tidak ada autokorelasi.

Untuk mengetahui ada atau tidaknya heteroskedastisitas yaitu dengan melakukan Uji Glejser dengan meregresi nilai absolut terhadap variabel independen, dengan ketentuan jika nilai signifikan di atas 0,05 maka memiliki arti tidak terjadi heteroskedastisitas. Hasil uji menunjukkan nilai signifikansi lebih dari 0,05 yang artinya model regresi bebas dari gejala heteroskedastisitas.

Tabel 5. Hasil Uji Heteroskedastisitas

\begin{tabular}{lcc}
\hline \multicolumn{1}{c}{ Model } & \multicolumn{1}{c}{ Sig. } & Keterangan \\
\hline Intellectual Capital (X1) & 0,051 & Lolos Uji \\
Good Corporate Governance (X2) & 0,066 & Lolos Uji \\
Pengungkapan Corporate Social Responsibility (X3) & 0,113 & Lolos Uji \\
\hline
\end{tabular}

Sumber: Data Penelitian, 2018

Besarnya nilai adjusted $\mathrm{R}$ square adalah sebesar 0,796 yang artinya sebesar 79,6 persen variasi kinerja keuangan perusahaan yang terdaftar di BEI dipengaruhi oleh Intellectual Capital, Good Corporate Governance, dan Pengungkapan Corporate Social Responsibility, sedangkan sisanya sebesar 20,4 persen dipengaruhi oleh faktor-faktor lain yang tidak dimasukkan ke dalam model penelitian.

$\mathrm{H}_{1}$ : Intellectual capital tidak berpengaruh terhadap kinerja keuangan

Berdasarkan hasil uji regresi linear berganda, diketahui bahwa variabel intellectual capital memiliki nilai koefisien beta positif sebesar 620,778 dengan nilai signifikansi sebesar 0,080. Nilai koefisien beta $>0$ mengindikasikan bahwa intellectual capitalberpengaruh positif namun tidak signifikan terhadap kinerja keuangan perusahaan yang terdaftar di BEI. Dengan demikian, $\mathrm{H}_{1}$ ditolak. $\mathrm{H}_{2}$ : Good corporate governance berpengaruh positif terhadap kinerja keuangan

Berdasarkan hasil uji regresi linear berganda, diketahui bahwa variabel penerapan good corporate governance memiliki nilai koefisien beta positif sebesar 2100,880 dengan nilai signifikansi sebesar 0,000. Nilai koefisien beta $>0$ mengindikasikan bahwa penerapan good corporate governance berpengaruh positif dan signifikan terhadap kinerja keuangan perusahaan yang terdaftar di BEI. Dengan demikian, $\mathrm{H}_{2}$ diterima.

$\mathrm{H}_{3}$ : Pengungkapan Corporate Social Responsibility berpengaruh positif terhadap kinerja keuangan

Berdasarkan hasil uji regresi linear berganda, diketahui bahwa variabel Pengungkapan Corporate Social Responsibility memiliki nilai koefisien beta positif sebesar 15904,898 dengan nilai signifikansi sebesar 0,008. Nilai koefisien beta $>0$ 
mengindikasikan bahwa Corporate Social Responsibility berpengaruh positif dan signifikan terhadap kinerja keuangan perusahaan yang terdaftar di BEI. Dengan demikian, $\mathrm{H}_{3}$ diterima.

Berdasarkan hasil uji statistik di atas menunjukan bahwa Intellectual Capital tidak berpengaruh terhadap kinerja keuangan perusahaan (ROE). Hal ini dapat dibuktikan dengan melihat hasil statistik deskriptif yang menunjukan nilai memiliki nilai rata-rata sebesar 2.1638, nilai standar deviasi sebesar 1.40539 . Nilai minimum sebesar -30 dan nilai maksimumnya sebesar 5.10. mengindikasikan bahwa intellectual capital tidak berpengaruh terhadap kinerja keuangan perusahaan. Hasil ini menolak hipotesis yang menduga adanya pengaruh positif dan signifikan intellectual capital terhadap kinerja keuangan perusahaan. Teori Resource-Based View Theory (RBT) menganggap perusahaan sebagai kumpulan sumber daya dan kemampuan dalam mengelola sumber daya yang dimiliki perusahaan. Berdasarkan teori yang dinyatakan oleh Stewart (1997) dalam Andreawan (2013) mendefinisikan "Modal intelektual sebagai bahan intelektual yang telah disahkan, ditangkap dan leverage untuk menciptakan kekayaan dengan memproduksi lebih tinggi nilai aset". Hasil penelitian ini menolak hipotesis yang menduga adanya pengaruh signifikan dari variabel intellectual capital terhadap kinerja keuangan perusahaan. Hal ini dapat disebabkan karena karakteristik subyek penelitian dalam penelitian ini, yaitu perusahaan dari semua sektor berbeda dengan kebanyakan subyek penelitian yang dilakukan peneliti lain yang menggunakan perusahaan dari salah satu sektor. Selain itu, Arah koefisien negatif intellectual capital terhadap kinerja keuangan perusahaan dikarenakan perhitungan IC dengan proksi SCE (Structural Capital Efficiency) dihitung dengan menggunakan data diperiode yang sama sehingga menunjukan hasil sebaran yang homogen, sedangkan manfaat dari intellectual capital seharusnya berdampak di periode yang akan datang atau besifat jangka panjang dan tidak langsung memberikan dampak pada periode yang sama. Hasil penelitian ini sejalan dengan penelitian yang dilakukan oleh Ariantini et al. (2017) dan Suroso et al. (2017). Namun tidak sejalan dengan penelitian (Andriana, 2014).

Berdasarkan hasil uji statistik di atas menunjukan bahwa Good Corporate Governance berpengaruh terhadap kinerja keuangan perusahaan. Hal ini dapat dibuktikan dengan melihat hasil uji regresi linear berganda, yang menunjukan bahwa variabel penerapan good corporate governance memiliki nilai koefisien beta positif sebesar 2100,880 dengan nilai signifikansi sebesar 0,000. menunjukan bahwa penerapan good corporate governance berpengaruh positif terhadap kinerja keuangan perusahaan dan $\mathrm{H}_{2}$ diterima. Legitimasi dapat dianggap sebagai menyamakan persepsi atau asumsi bahwa tindakan yang dilakukan oleh suatu organisasi selaras dengan tindakan yang diinginkan, pantas ataupun sesuai dengan sistem nilai, norma, kepercayaan yang berkembang di masyarakat. Berdasarkan teori stakeholder, Freeman et al. (2007) mendiskusikan tentang pengaruh stakeholder dalam keputusan yang diambil perusahaan. Peran utama dari manajemen perusahaan adalah untuk menilai pentingnya memenuhi permintaan stakeholder dalam rangka untuk mencapai tujuan strategis perusahaan. Ketika derajat kekuatan stakeholder meningkat, maka pentingnya laporan informasi untuk memenuhi permintaan stakeholder juga meningkat. Selanjutnya, harapan dan kekuatan berbagai macam stakeholder dapat berubah 
sewaktu-waktu, sehingga perusahaan harus menyesuaikan secara terus menerus strategi operasional dan pelaporannya, dan Good Corporate Governance merupakan sistem dan struktur yang baik untuk mengelola perusahaan dengan tujuan meningkatkan nilai pemegang saham serta mengakomodasi berbagai pihak yang berkepentingan dengan perusahaan (stakeholders) dan sebagai struktur, sistem, dan proses yang digunakan oleh organ-organ perusahaan sebagai upaya untuk memberikan nilai tambah perusahaan dalam jangka panjang, dengan tetap memperhatikan kepentingan stakeholder lainnya, berlandasarkan peraturan perundang-undangan dan norma yang berlaku, sehingga dapat meningkatkan minat stakehorlders untuk berinvestasi dan meningkatkan kinerja keuangan perusahaan.

Good Corporate Governance adalah seperangkat peraturan yang mengatur hubungan antara pemegang saham, pengurus (pengelola) perusahan, pihak kreditur, pemerintah, karyawan serta para pemegang kepentingan internal dan eksternal lainnya yang berkaitan dengan hak-hak dan kewajiban mereka atau dengan kata lain suatu sistem yang mengendalikan perusahaan (FCGI, 2011). Hasil penelitian ini membuktikan bahwa Good Corporate Governance berpengaruh terhadap kinerja keuangan perusahaan dan sejalan dengan penelitian yang dilakukan oleh Wati (2012) dan Silvia \& Andayani (2014). Namun tidak sejalan dengan hasil penelitian Kartikasari (2016), Ariantini et al. (2017) dan Maryanti \& Fithri (2017).

Berdasarkan hasil uji regresi linear berganda, diketahui bahwa variabel Corporate Social Responsibility memiliki nilai koefisien beta positif sebesar 15904,898 dengan nilai signifikansi sebesar 0,008 dengan demikian $\mathrm{H}_{3}$ diterima. Menurut teori Stakeholders, perusahaan bukanlah entitas yang hanya beroperasi untuk kepentingan sendiri, namun harus memberikan manfaat kepada seluruh stakeholder-nya. Berdasarkan teori yang dinyatakan oleh (Wang et al., 2016), Pengungkapan Corporate Social Responsibility telah menjadi lebih umum dan terlihat dalam perusahaan sebagai mekanisme untuk memberi energi dan memotivasi para pemangku kepentingan, serta mengelola persepsi dan harapan masyarakat tentang peran dan kegunaan bisnis di masyarakat dan masyarakat di luar fungsi inti dalam memproduksi dan menjual barang ke pasar konsumen yang ditentukan sehingga mendapatkan loyalitas pelanggan dan dapat berdampak pada peningkatan kinerja keuangan. Hasil penelitian ini membuktikan bahwa Corporate Social Responsibility berpengaruh terhadap kinerja keuangan dan sejalan dengan penelitian yang dilakukan oleh Flammer (2013), Jizi et al. (2014), Maryanti \& Fithri (2017), Silvia \& Andayani (2014), Ariantini et al. (2017). Namun tidak sejalan dengan hasil penelitian (Candrayanthi \& Saputra, 2013).

\section{SIMPULAN}

Intellectual capital terbukti tidak berpengaruh terhadap kinerja keuangan. Penerapan good corporate governance terbukti berpengaruh positif terhadap kinerja keuangan. Corporate Social Responsibility terbukti berpengaruh positif terhadap kinerja keuangan.

Penelitian selanjutnya diharapkan dapat menambah jumlah sampel dan memperpanjang waktu pengamatan. Dapat menggunakan indikator lain selain 
ROE misalnya: ROI, NPM dan EPS, ROA, PBV untuk menilai kinerja keuangan suatu perusahaan.Disarankan Bagi Investor, Penelitian ini diharapkan sebagai bahan pertimbangan para investor dalam menentukan dan memutuskan investasi yang akan dilakukan, karena setiap investor menginginkan prospek yang lebih baik bagi kinerja keuangan perusahaannya di masa depan. Disarankan Bagi Pemerintah, Penelitian ini diharapkan sebagai bahan pertimbangan pemerintah dan pihak-pihak lainnya dalam memutuskan pengambilan kebijakan yang akan ditempuh melalui peningkatan investasi yang dilihat dari kinerja keuangan perusahaan yang terdaftar di Bursa Efek Indonesia (BEI).

\section{REFERENSI}

Andreawan, A. (2013). Analisis Intellectual Capital, Mekanisme Corporate Governance dan Corporate Social Responsibility terhadap Financial Performance (Studi Empiris pada Perusahaan Perbankan Go publik yang Terdaftar di Bursa Efek Indonesia Tahun 2009-2011). Fakultas Ekonomi dan Bisnis Universitas Muhammadiyah Surakarta. Universitas Muhammadiyah Surakarta.

Andriana, D. (2014). Pengaruh Intellectual Capital terhadap Kinerja Keuangan Perusahaan (Studi pada Perusahaan Pertambangan dan Manufaktur yang Terdaftar di Bursa Efek Indonesia 2010 - 2012). Jurnal Riset Akuntansi Dan Keuangan, 2(1), 251-260.

Anggit, I. (2019). Dukung Unicorn, Sri Mulyani Lakukan Ini ke Startup. CNBC Indonesia. Retrieved from https://www.cnbcindonesia.com/fintech/20190218155841-3756195/dukung-unicorn-sri-mulyani-lakukan-ini-ke-startup

Ariantini, I. G. A., Yuniarta, G. A., \& Sujana, E. (2017). Pengaruh Intellectual Capital, Corporate Social Responsibility, dan Good Corporate Governance terhadap Kinerja Perusahaan (Studi Kasus pada Perusahaan Manufaktur yang Terdaftar di Bursa Efek Indonesia tahun 2011-2015). E-Journal S1 Ak Universitas Pendidikan Ganesha, 7(1).

Candrayanthi, A. A. A., \& Saputra, I. D. G. D. (2013). Pengaruh Pengungkapan Corporate Social Responsibility Terhadap Kinerja Perusahaan (Studi Empiris Pada Perusahaan Pertambangan Di Bursa Efek Indonesia). E-Jurnal Akuntansi Universitas Udayana, 4(1), 141-158. Retrieved from https://ojs.unud.ac.id/index.php/Akuntansi/article/view/5899

Devi, B. E., \& Budiono, E. (2017). Pengaruh Intellectual Capital Terhadap Kinerja Keuangan Perusahaan ( Studi Kasus pada Perusahaan Elektronik, Otomotif dan Komponen yang terdaftar di Bursa Efek Indonesia ( BEI ) periode 20112015 ), 4(1), 491-500.

Dhaliwal, D., Li, O. Z., Tsang, A., \& Yang, Y. G. (2014). Corporate social responsibility disclosure and the cost of equity capital: The roles of stakeholder orientation and financial transparency. Journal of Accounting and Public Policy, 33(4), 328-355. https://doi.org/10.1016/j.jaccpubpol.2014.04.006

Embu, W. S. (2017). Ini daftar perusahaan pemilik tata kelola terbaik seIndonesia. Merdeka.Com. Retrieved from https://www.merdeka.com/uang/ini-daftar-perusahaan-pemilik-tata- 
kelola-terbaik-se-indonesia.html

FCGI. (2011). Seri Tata Kelola Perusahaan (Corporate Governance): Corporate Governance (Tata Kelola Perusahaan) (3rd ed.). Jakarta.

Flammer, C. (2013). Corporate Social Responsibility and Shareholder Reaction: The Environmental Awareness of Investors. Academy of Management Journal, $56(3), 758-781$.

Freeman, R. E., Harrison, J. S., \& Parmar, B. (2007). Stakeholder capitalism. Journal of Business Ethics, 74(4).

Ghazali, N. A. M. (2007). Ownership structure and corporate social responsibility disclosure: some Malaysian evidence. Corporate Governance: The International Journal of Business in Society, 7(3), 251-266. https:// doi.org/10.1108/14720700710756535

Ioannou, I., \& Serafeim, G. (2015). The impact of corporate social responsibility on investment recommendations: Analysts' perceptions and shifting institutional logics. Strategic Management Journal, 36(7), 1053-1081. https://doi.org/10.1002/smj.2268

Jizi, M. I., Salama, A., Dixon, R., \& Stratling, R. (2014). Corporate Governance and Corporate Social Responsibility Disclosure: Evidence from the US Banking Sector. Journal of Business Ethics, 125(4), 601-615.

Jizi, M., Salama, A., Dixon, R., \& Stratling, R. (2014). Corporate governance and corporate social responsibility disclosure: evidence from the US banking sector. Journal of Business Ethics, 44(April), 0-103. https:/ / doi.org/10.1063/1.2756072

Kartikasari, Y. D. (2016). Pengaruh Good Corporate Governance dan Modal Intelektuak Terhadap Kinerja Keuangan Pada Perusahaan Sektor Keuangan Yang Terdaftar di Bursa Efek Indonesia Tahun 2011-2015. Program Studi Akuntansi Jurusan Pendidikan Akuntansi Fakultas Ekonomi Universitas Negeri Yogyakarta. Universitas Negeri Yogyakarta.

Mary, F. F. P. R. (2017). Pengaruh Struktur Good Corporate Governance (GCG) Terhadap Kinerja Keuangan Perusahaan pada Sektor Pertambangan di Bursa Efek Indonesia (BEI). Fakultas Ekonomi Dan Bisnis Universitas Lampung. Universitas Lampung.

Maryanti, E., \& Fithri, W. N. (2017). Corporate Social Responsibilty, Good Corporate Governance, Kinerja Lingkungan Terhadap Kinerja Keuangan Dan Pengaruhnya Pada Nilai Perusahaan Abstrak Pendahuluan. Journal Of Accounting Science, 1(1), 21-37. https://doi.org/10.21070/jas.v1i1.773 Januari

Moon, A. (2013). Makalah-Tanggung Jawab Sosial Perusahaan (CSR). I-Makalah. Retrieved from http://i-makalah.blogspot.com/2013/02/tanggung-jawabsosial-perusahaan-csr.html

Mualim, N. (2009). Pengaruh Intellectual Capital Terhadap Kinerja Keuangan Pada Perusahaan yang Terdaftar di Bursa Efek Indonesia. Bandung.

Prasetio, F. (2015). Pengaruh Intellectual Capital Terhadap Kinerja Keuangan Perusahaan (Studi Empiris Pada Perusahaan Perbankan Dan Asuransi Yang Terdaftar Di Bursa Efek Indonesia Tahun 2011-2013). Fakultas Ekonomika Dan Bisnis Universitas Diponegoro. Universitas Diponegoro.

Pulic, A. (1998). Measuring The Performance Of Intellectual Potential In 
Knowledge Economy. Paper Presented at the 2nd McMaster Word Congress on Measuring and Managing Intellectual Capital by the Austrian Team for Intellectual Potential.

Puniayasa, I. . M., \& Triaryati, N. (2016). Pengaruh Good Corporate Governance, Struktur Kepemilikan dan Modal Intelektual terhadap Kinerja Keuangan Perusahaan yang Masuk dalam Indeks CGPI. E-Jurnal Manajemen Unud, 5(8), 5304-5332.

Razafindrambinina, D. (2011). Intellectual Capital and Corporate Financial Performance of Selected Listed Companies in Indonesia. Malaysian Journal of Economic Studies, 48(6), 61-77.

Rodriguez-Fernandez, M. (2016). Social responsibility and financial performance: The role of good corporate governance. BRQ Business Research Quarterly, 19(2), 137-151. https:// doi.org/10.1016/j.brq.2015.08.001

Sari, N. L. K. M., \& Suaryana, I. G. N. A. (2013). Pengaruh Pengungkapan CSR terhadap Kinerja Keuangan dengan Kepemilikan Asing sebagai Variabel Moderator. E-Jurnal Akuntansi Universitas Udayana, 3(2), 248-257.

Sharabati, A. A. A., Jawad, S. N., \& Bontis, N. (2010). Intellectual Capital and Business Performance in The Pharmaceutical Sector of Jordan. Management Decision, 48(1), 105-131.

Silvia, N., \& Andayani. (2014). Pengaruh Good Corporate Governance dan Pengungkapan Corporate Socila Responsibility Terhadap Kinerja Keuangan. Jurnal Ilmu Dan Riset Akuntansi, 3(3), 1-17.

Simarmata, R. (2015). Pengaruh Intellectual Capital terhadap Kinerja Keuangan dan Nilai Perusahaan Perbankan yang Terdaftar di Bursa Efek Indonesia. Universitas Negeri Semarang.

Stanley, C. (2017). The Impact of Investing Environment on Financial Performance. International Research Journal of Applied Finance, VII(June), 172179. https:// doi.org/10.0708/article

Supriatna, N., Triantoro, A., \& Rustandi, R. (2013). Pengaruh Intellectual Capital terhadap Kinerja Keuangan Pada Perusahaan Retail yang Terdaftar di Bursa Efek Indonesia (BEI) Pada Tahun 2009-2011. Jurnal Riset Akuntansi Dan Keuangan, 1(1), 23-37.

Suroso, S., Widyastuti, T., Salim, M. N., \& Setyawati, I. (2017). Intellectual Capital and Corporate Governance in Financial Performance Indonesia Islamic Banking. International Journal of Economics and Financial Issues, 7(11), 96-103.

Ulum, A. S. (2015). The Influence Of Profitability and Capital Structure on Firm Value (Study on Manufacturing Industries Listed at Indonesia Stock Exchange for Periods 2008-2012). Media Mahardhika, 14(1), 79-97. Retrieved from http:/ / eprints.perbanas.ac.id/1854/

Ulum, I. (2008). Intellectual Capital Performance Sektor Perbankan di Indonesia. Jurnal Akuntansi Dan Keuangan, 10(2), 77-84.

Utami, N. W. (2017). 4 Penyebab Tutupnya Bisnis 7-Eleven di Indonesia. Www.Jurnal.Id. Retrieved from https://www.jurnal.id/id/blog/2017-4penyebab-tutupnya-bisnis-7-eleven-di-indonesia/

Wang, Tong, \& Takeuchi. (2016). Corporate Social Responsibility: An Overview and New Research Directions Thematic Issue on Corporate Social Responsibility. Journal of Academy Management, 59(2), 534-544. 
Wati, M. (2012). Pengaruh Praktek Good Corporate Governance Terhadap Kinerja Keuangan Perusahaan Di BEI (No. 1). Jurnal Manajemen, Program Studi Manajemen Fakultas Ekonomi Universitas Negeri Padang (Vol. 01). Padang. 